\begin{tabular}{|l|l|l|}
\hline \multicolumn{2}{|c|}{ PublisherInfo } \\
\hline \hline PublisherName & $:$ & BioMed Central \\
\hline \hline PublisherLocation & $:$ & London \\
\hline \hline PublisherImprintName & $:$ & BioMed Central \\
\hline \hline
\end{tabular}

\title{
An example of a 'riboswitch'
}

\begin{tabular}{|l|l|l||}
\hline \multicolumn{2}{|c|}{ ArticleInfo } \\
\hline \hline ArticleID & $:$ & 4617 \\
\hline \hline ArticleDOI & $:$ & $10.1186 /$ gb-spotlight-20021022-02 \\
\hline \hline ArticleCitationID & $:$ & spotlight-20021022-02 \\
\hline \hline ArticleSequenceNumber & $:$ & 283 \\
\hline \hline ArticleCategory & $:$ & Research news \\
\hline \hline ArticleFirstPage & $:$ & 1 \\
\hline \hline ArticleLastPage & $:$ & 2 \\
\hline \hline & & RegistrationDate : 2002-10-22 \\
ArticleHistory & $:$ & OnlineDate $\quad$ 2002-10-22 \\
\hline \hline ArticleCopyright & $:$ & BioMed Central Ltd2002 \\
\hline \hline ArticleGrants & $:$ & \\
\hline \hline ArticleContext & $:$ & 130593311 \\
\hline \hline
\end{tabular}


It has been thought that genes involved in thiamine (vitamin B1) biosynthesis might be controlled by a thiamine pyrophosphate-dependent sensor/regulatory protein, but no such protein has been shown to exist. In the October 17 Nature, Wade Winkler and colleagues from Yale University, New Haven, Connecticut, USA, show that mRNAs bind thiamine derivatives directly and this interaction regulates bacterial gene expression without the need for protein cofactors (Nature, October 16, 2002, doi:10.1038/ nature01145).

Winkler et al.used $\beta$-galactosidase translational fusion constructs from which they generated DNA templates and then RNA fragments. The resulting RNAs were analysed using a structure probing process to reveal whether the RNAs undergo structure modulation upon binding of ligands.

Using this system, Winkler et al. observed that the mRNAs encoding enzymes involved in thiamine biosynthesis in Escherichia coli can directly bind thiamine or its pyrophosphate derivative. The mRNAeffector complex adopts a distinct structure that sequesters the ribosome-binding site and leads to a reduction in gene expression.

"Although new metabolite-binding mRNAs are likely to emerge as evolution progresses, it is possible that the known riboswitches are 'molecular fossils' from the RNA world," conclude the authors.

\section{References}

1. Winkler W, Nahvi A, Breaker RR: Thiamine derivatives bind messenger RNAs directly to regulate bacterial gene expression. Nature, October 16, 2002, doi:10.1038/nature01145., [http://www.nature.com/nature/]

2. Yale University, [http://www.yale.edu/] 